\title{
The lithostratigraphy of the lower Devonian formations of the Eisleck region (northern Luxembourg). Comparison with their Belgian lateral equivalents
}

\author{
LÉON DEJONGHE $^{1 *}$, ROBERT COLBACH ${ }^{2} \&$ ERIC GOEMAERE ${ }^{1}$
}

${ }^{1}$ Royal Belgian Institute of Natural Sciences, Geological Survey of Belgium, Jenner Street 13, B-1000 Brussels, Belgium; leon. dejonghe@naturalsciences.be,eric.goemaere@naturalsciences.be.

2 Service géologique du Luxembourg/Geological Survey of Luxembourg, rue du Chemin de fer, 23, L-8057 Bertrange, Luxembourg; robert.colbach@pch.etat.lu.

*corresponding author

ABSTRACT. The Eisleck region forms the northern third of the territory of the Grand-Duchy of Luxembourg and also represents the southeastern part of the Ardennes. The underground is made up of detrital rocks (shales and sandstones) of lower Devonian age folded during the Variscan orogeny. They have undergone strong diagenesis reaching up to weak metamorphism. In order to allow modern geological mapping of this area, a lithostratigraphical framework is proposed. Seven formations are considered and their lithological characteristics, thicknesses and paleogeographical settings are described. References to their paleontological content are also mentioned. Comparisons with their Belgian lateral equivalents are drawn in order to facilitate the cross-border comprehension of geological maps.

KEYWORDS: lower Devonian, Pragian, Emsian, lithostratigraphy, correlation, Eisleck region, Luxembourg, Belgium.

\section{Introduction}

The Grand-Duchy of Luxembourg is divided into two main geographical regions, the Eisleck (Oesling in German) to the north $(32 \%$ of the area) and the Guttland to the south ( $68 \%$ of the area). They correspond to two main geological provinces of the country (Fig. 1).

In the Eisleck region, lithostratigraphic units are of lower Devonian (Pragian and Emsian) age; they were folded during the Variscan orogeny) and belong to the SE part of the Ardenne Anticlinorium. From NNW to SSE, the main tectonic structures are: the Houffalize Synclinorium, the BastogneStubach (Stupbach) Anticlinorium, the Neufchâteau-WiltzEifel Synclinorium and the Givonne Anticlinorium. In detail, these large scale structures are complicated by numerous secondary synclines and anticlines.

In the Guttland region, lithostratigraphic units belong to the Mesozoic era (Triassic and Jurassic); they are relatively flat-lying and form the northeastern tip of the Paris Basin, the so-called "Gulf of Trier-Luxembourg".
The oldest contribution to geology of the Eisleck region dates back to 1828 and is due to Steininger. The works of Wies (1867) and Wies \& Siegen (1877) do not provide a lot of substantial additional information, except on the mineral wealth contained in the grounds of the Eisleck region. The first important contribution concerning the geological subdivisions of the Eisleck region is due to Gosselet (1885). Up to recently, the Luxembourg Devonian stratigraphy mainly referred to Lucius (1950). Lucius has indeed published in 1949 a geological map at the scale 1 to 50,000 (Detailed geological map of Luxembourg, Sheet 8, Wiltz) in which a stratigraphic pattern was proposed and which has been used up to now. Lucius's work (1950) contains a detailed description of his observations and geological concepts. Previously, the geological subdivisions given by Gosselet $(1885)$ were adapted in various works by Asselberghs (1912, 1913, 1927, 1932, 1941, 1946) and Lucius (1913, 1937, 1940, 1947a). Later, Furtak (1965) and Konrad \& Wachsmut (1973) considered that certain subdivisions of Lucius could not be ascertained in the field. Dejonghe (2015) reassessed the question for geological mapping purposes (Table 1).

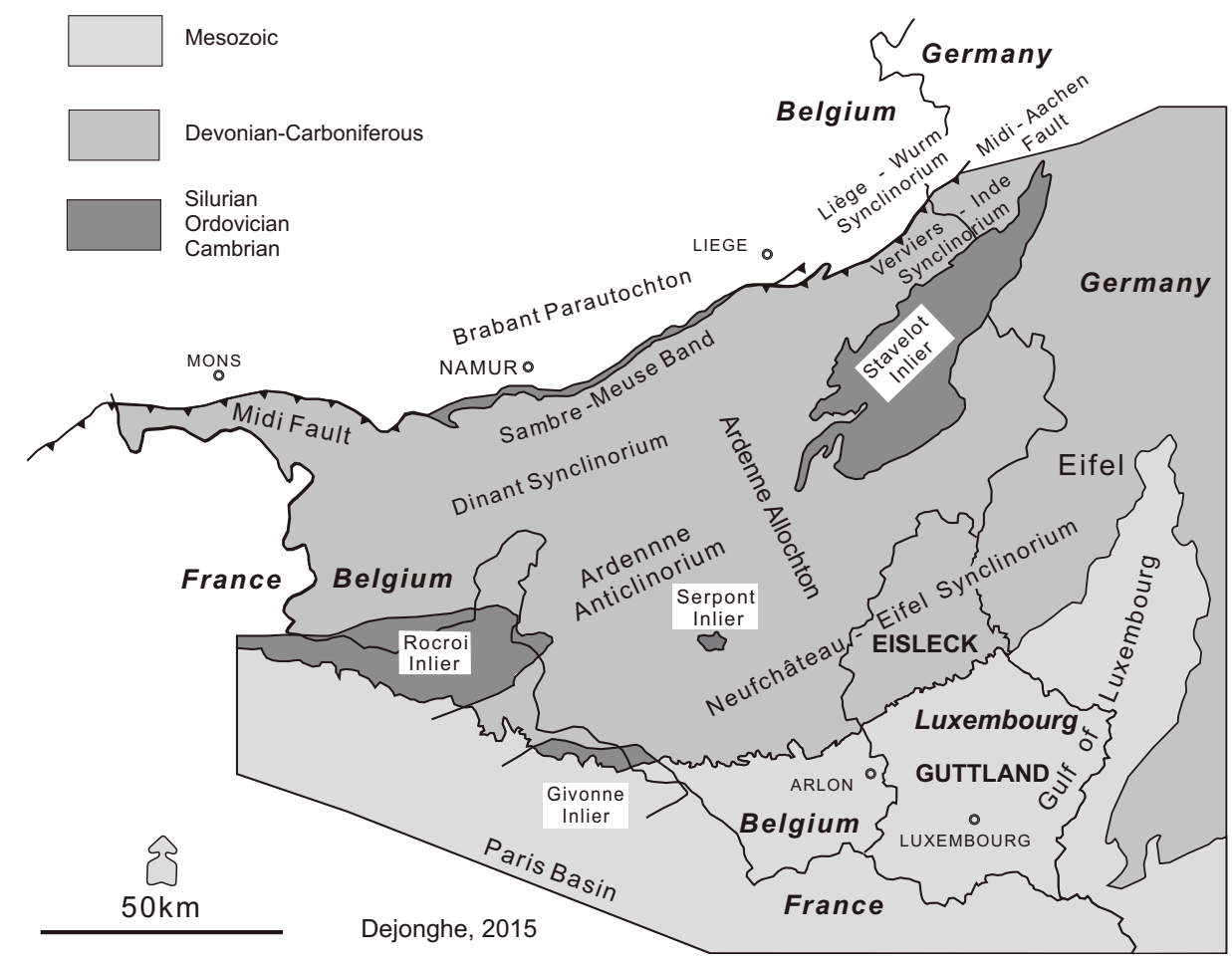

Figure 1. Location map of the studied area. 
Asselberghs (1946) \& Lucius (1950) made extensive reviews on all published works on the lower Devonian in Belgium and Luxembourg prior to their respective papers.

A revision of the geological maps at a scale of 1 to 25,000 started in Luxembourg in 1971, but it mainly concerned the Guttland part so far. During the works on a first sheet in the Eisleck region (no. 1, "Troisvierges", Dejonghe (2015), completely in the lower Devonian units), the need for a stratigraphic framework arose.

As detailed geological mapping started in Wallonia in 1990, comparisons with Belgian lateral lithostratigraphic equivalents were performed in order to facilitate the comprehension of cross-border geological maps. Bultynck \& Dejonghe (2001) provided descriptions of the Devonian lithostratigraphic units used in Belgium. The National Commission for Stratigraphy
Belgium (http://ncs.naturalsciences.be) updates information continuously.

The various stratigraphic contributions are summarized in Table 1. Comparisons between the Eisleck region and corresponding Belgian lower Devonian formations are schematized in Figure 2. This paper is devoted to the geological formations of the Eisleck region, following Hedberg's rules (Hedberg, 1976). The spelling of certain terms and localities can differ according to the different authors. The original writing has always been preserved.

A location map of localities mentioned in the current paper is supplied in Figure 3. Furthermore, the coordinates (longitude E/latitude $\mathrm{N}$ ) of the type localities are given in the WGS84 system.

\begin{tabular}{|c|c|c|c|c|c|c|c|c|}
\hline & Gosselet, 1885 & $\begin{array}{c}\text { Asselberghs, } \\
1912,1913,1932\end{array}$ & Lucius, 1947a,b & Lucius, 1949, 1950, 1955 & $\begin{array}{l}\text { Furtak, } \\
1965\end{array}$ & $\begin{array}{c}\text { Konrad \& } \\
\text { Wachsmut, } \\
1973 \\
\end{array}$ & $\begin{array}{c}\text { Bultynck \& } \\
\text { Dejonghe, } \\
2001\end{array}$ & Dejonghe, 2015 \\
\hline \multirow{4}{*}{ 蛋 } & $\begin{array}{l}\text { upper Eifelian - } \\
\text { Schistes de Wiltz } \\
\text { Quartzite de } \\
\text { Berlé }\end{array}$ & $\begin{array}{c}\text { Em2b- Grauwacke } \\
\text { de Wiltz }\end{array}$ & Schiste de Wiltz & $\begin{array}{c}\text { E3 - Schistes de Wiltz } \\
\text { E3 q - At the base, Berlé } \\
\text { quartzite }\end{array}$ & & $\begin{array}{l}\text { Schiefer von } \\
\text { Wiltz }\end{array}$ & $\begin{array}{l}\text { Hierges } \\
\text { (HIE) }\end{array}$ & $\begin{array}{l}\text { Berlé Mbr } \\
\text { (BER) }\end{array}$ \\
\hline & $\begin{array}{l}\text { lower Eifelian - } \\
\text { Schistes rouges } \\
\text { de Clervaux }\end{array}$ & $\begin{array}{c}\text { Em2a - Quartzite } \\
\text { de Berlé et Schistes } \\
\text { bigarrés de } \\
\text { Clervaux }\end{array}$ & $\begin{array}{c}\text { Schiste rouge de } \\
\text { Clervaux et } \\
\text { Quartzite de } \\
\text { Berlé }\end{array}$ & $\begin{array}{c}\text { E2 - Couches bigarrées de } \\
\text { Clervaux }\end{array}$ & D & $\begin{array}{l}\text { Bunte Schiefer } \\
\text { von Clerf }\end{array}$ & $\begin{array}{l}\text { Chooz } \\
(\mathrm{CHO})\end{array}$ & $\begin{array}{c}\text { Berlé Mbr } \\
\text { (BER) } \\
\text { Clervaux } \\
\text { (CLE) }\end{array}$ \\
\hline & \multirow{2}{*}{$\begin{array}{c}\text { North } \\
\text { Quartzophyllades } \\
\text { de Heinerscheid } \\
\text { South } \\
\text { Quartzophyllades } \\
\text { de Schuttbourg }\end{array}$} & \multirow{2}{*}{$\begin{array}{c}\text { Em1 - } \\
\text { Quartzophyllades } \\
\text { d'Ebly, de } \\
\text { Heinerscheid et de } \\
\text { Schutbourg } \\
\text { Schistes, grès et } \\
\text { quartzophyllades } \\
\text { de Schutbourg à } \\
\text { Sp. Hercyniae }\end{array}$} & \multirow[t]{2}{*}{$\begin{array}{l}\text { Quartzophyllades } \\
\text { de Schuttbourg }\end{array}$} & $\begin{array}{c}\text { E1b -Quartzophyllades de } \\
\text { Schuttbourg } \\
\text { Frequent rather thick } \\
\text { units of quartzite and } \\
\text { mixed quartzite-phyllites } \\
\text { (quartzophyllades in } \\
\text { French) intercalated in } \\
\text { shales and phyllites }\end{array}$ & \multirow[t]{2}{*}{ C } & \multirow{7}{*}{$\begin{array}{l}\text { Partly Emsian } \\
\text { (E1) to Pragian }\end{array}$} & $\begin{array}{l}\text { Vireux } \\
\text { (VIR) }\end{array}$ & $\begin{array}{c}\text { Schuttbourg Mbr } \\
\text { (SCH) }\end{array}$ \\
\hline & & & & $\begin{array}{c}\text { E1a - Schistes de } \\
\text { Stolzembourg } \\
\text { Well stratified shales. } \\
\text { Mixed quartzite-phyllites } \\
\text { and rare quartzite beds }\end{array}$ & & & $\begin{array}{l}\text { Pesche } \\
\text { (PES) }\end{array}$ & $\begin{array}{l}\text { Stolzembourg } \\
\text { Mbr (STO) }\end{array}$ \\
\hline 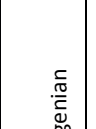 & \multirow{5}{*}{$\begin{array}{c}\text { North } \\
\text { Phyllades de } \\
\text { Trois-Vierges } \\
\text { Schistes de Bas- } \\
\text { Bellain }\end{array}$} & \multirow{2}{*}{$\begin{array}{c}\text { Sg3 - Phyllades } \\
\text { bleu foncé, } \\
\text { intercalations de } \\
\text { grès gris, gris clair } \\
\text { ou gris verdâtre et } \\
\text { de } \\
\text { quartzophyllades } \\
\text { Faciès de St Vith }\end{array}$} & \multirow{2}{*}{$\begin{array}{l}\text { Couches de St- } \\
\text { Vith (faciès } \\
\text { gréseux) }\end{array}$} & \multirow{2}{*}{$\begin{array}{l}\text { Sg3 - Coarse-grained and } \\
\text { compact shales, badly } \\
\text { stratified, with rare } \\
\text { argillaceous sandstone } \\
\text { beds } \\
\text { Sg3s - Sandstone facies : } \\
\text { Schistes de Bas-bellain }\end{array}$} & \multirow{4}{*}{ B } & & $\begin{array}{c}\text { Jupille } \\
\text { (JUP) + } \\
\text { Pèrnelle } \\
\text { (PER) } \\
\end{array}$ & Jupille (JUP) \\
\hline 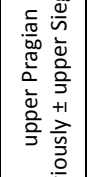 & & & & & & & $\begin{array}{l}\text { La Roche } \\
\text { (LAR) }\end{array}$ & $\begin{array}{c}\text { Kautenbach- } \\
\text { Troisvierges (KAT) }\end{array}$ \\
\hline ญั & & $\begin{array}{l}\text { Ardoises = faciès } \\
\text { de Neuchâteau - } \\
\text { Asselberghs, } 1946\end{array}$ & $\begin{array}{c}\text { Couches de } \\
\text { Martelange } \\
\text { (faciès schisteux) }\end{array}$ & $\begin{array}{l}\text { Sg3a - at the base, locally } \\
\text { roofing slate facies } \\
\text { (Dachschiefer) }\end{array}$ & & & $\begin{array}{l}\text { Martelange } \\
\quad(\mathrm{MTL})\end{array}$ & $\begin{array}{l}\text { Martelange Mbr } \\
\quad \text { (MTL) }\end{array}$ \\
\hline 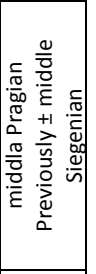 & & $\begin{array}{c}\text { Sg2b-Phyllades de } \\
\text { Neufchâteau, de } \\
\text { Trois-Vierges et de } \\
\text { Martelange } \\
\text { Sg2a- } \\
\text { Quartzophyllades } \\
\text { de Longlier et de } \\
\text { Léglise }\end{array}$ & $\begin{array}{l}\text { Couches de } \\
\text { Longlier (faciès } \\
\text { gréseux) } \\
\text { Couches de } \\
\text { Bouillon (faciès } \\
\text { argilocalcareux) }\end{array}$ & $\begin{array}{l}\mathrm{Sg} 2 \text { - Sandstone and } \\
\text { sandy shales, compact }\end{array}$ & & & Villé (VIL) & Villé (VIL) \\
\hline 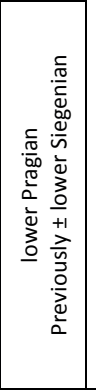 & & $\begin{array}{c}\text { Faciès d'Anlier } \\
\text { phyllade ardoisier } \\
\text { bleu foncé, } \\
\text { quartzophyllades, } \\
\text { grès } \\
\text { feldspathiques, } \\
\text { grès quartzites } \\
\text { Sg1 - Schistes } \\
\text { phylladeux de } \\
\text { Tournay ; phyllades } \\
\text { avec quartzites et } \\
\text { grès }\end{array}$ & $\begin{array}{c}\begin{array}{c}\text { Couches d'Anlier } \\
\text { (grès et schiste) }\end{array} \\
\text { Couches d'Anor } \\
\text { (schiste et } \\
\text { quartzite blanc) }\end{array}$ & $\begin{array}{l}\text { Sg } 1 \text { - Black and blue } \\
\text { phyllite and gray mixed } \\
\text { quartzitz-phyllites }\end{array}$ & A & & $\begin{array}{l}\text { Mirwart } \\
\text { (MIR) }\end{array}$ & Mirwart (MIR) \\
\hline
\end{tabular}

Table 1. Lower Devonian stratigraphic contributions related to the Eisleck and Belgium. 
Belgium

$\leftrightarrow$

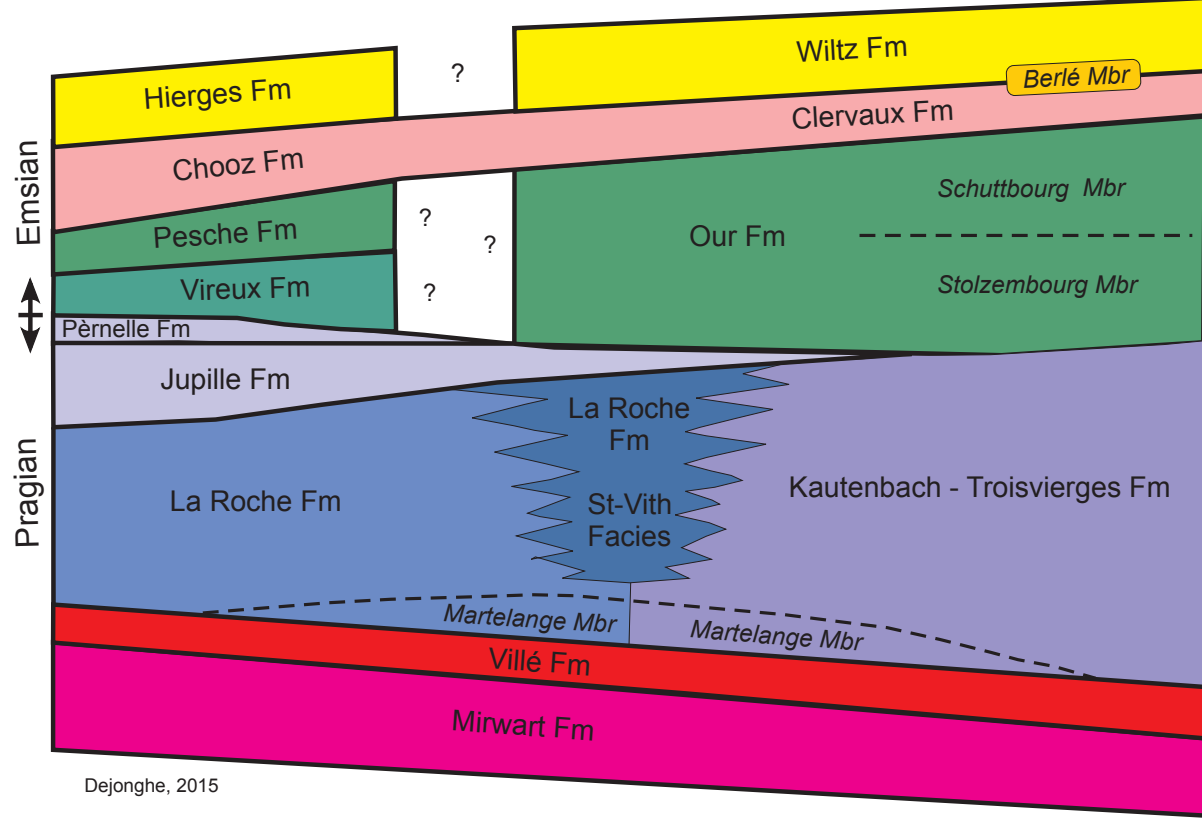

Figure 2. Synthetic cross-section showing relationships between formations in Luxembourg and in Belgium. Thicknesses are not at scale.

\section{Description of the lithostratigraphic units}

Seven formations are distinguished in the lower Devonian of the Eisleck region. They are named, from bottom to top: Mirwart, Villé, Kautenbach-Troisvierges, Jupille, Our, Clervaux and Wiltz (Table 1, Fig. 2). Except the Clervaux Formation, characterized by variegated colors, all these formations contain dark gray-blue shales and phyllites which are often lithologically predominant. Sandstone and quartzite beds and series of beds occasionally occur, mainly in the lower and middle Pragian, but become more and more abundant in the upper Pragian and in the Emsian. These formations differ from each other by different lithological proportions and by (scarce) fossil occurrences. Based on an isolated outcrop, it is often very difficult to determine with certainty the formation attributed to. Correlations between different outcrops require observations on relatively long and continuous cross-sections or on series of multiple smaller outcrops.

Mosar (1987) determined that the intensity of metamorphism in the Eisleck region varies between deep diagenesis and epizonal metamorphism: upper Emsian rocks reflect an anchizonal and slightly epizonal metamorphism, middle and lower Emsian rocks are affected by an anchizonal and epizonal metamorphism and metamorphism in Pragian rocks is clearly epizonal. In the Eisleck region, metamorphism intensity is thus very weak to weak.

In French, the word "schiste" is used to describe a sedimentary rock composed of clay-sized and silt-sized particles which splits along planes of cleavage. When the rock is very fine-grained and the cleavage very strong, the French term "phyllade" is commonly preferred. As the word "schist" refers in English to a clearly metamorphic rock, we prefer to translate the French word "schiste" by "shale". The French word "phyllade" is translated by "phyllite". The word "slate" ("phyllade ardoisier" in French) refers to an argillaceous rock affected by a very pronounced foliation cleavage. In the older French literature, the word "quartzophyllade" is very common and is most commonly described as a mixed rock made up of $\mathrm{mm}$ to $\mathrm{cm}$ alternations of shales (or phyllites) and sandstones (or quartzites).

Regarding the paleontological works related to the stratigraphy of lower Devonian in this area, the pioneer works of Leblanc (1923), Asselberghs \& Leblanc (1934) and Asselberghs (1946) have to be mentioned. They provide lists of macrofossils and localities where they were found. Paleontological investigations of Asselberghs (1946) are summarized (pp. 326-346) and often mentioned in the lists of fossils detailed by Lucius (1950, pp. 54-62). Kräusel \& Weyland (1930), Lippert (1937, 1939), Solle (1937), Fuchs (1989), Franke (2006a,b), Franke (2016), Basse \& Franke (2006), Plusquellec \& Franke (2016), Plusquellec et al. (2016) and Poschmann \& Franke (2006) also conducted paleontological studies in this field. In summary, these works indicate that the Ville Formation is of Pragian age, that the Stolzembourg and Schuttbourg units of Lucius $(1949,1950)$ are of lower Emsian age, that the Clervaux shales tend to have a middle Emsian age and that the Berlé Quartzite as well the Wiltz shales belong to units from the upper Emsian.

On the basis of 40 palynological samples, Steemans et al. (2000) made a preliminary survey of the palynological content of the lower Devonian in the Eisleck. Miospores allowed a dating of many samples, most ranging from Pragian to Emsian. Only 2 species were characteristic of the Lochkovian and were likely reworked. A complementary study on 60 samples from the North of Luxembourg was also undertaken by Steemans \& Brasseur (1999). Their results pointed out that the Emsian-Eifelian limit was never reached. But they also underline that the continental origin of the organic matter implies that the layers are either continental or nearshore marine. Furthermore, the thermal alteration, which varies with the age of the samples, is more pronounced in the Pragian and the early Emsian than in the late Emsian.

\subsection{Mirwart Formation - MIR}

Type locality situated in Belgium, along the railway section crossing Mirwart (Fig. 3); WGS84 coordinates: 5.26/50.06.

This formation does only occur on a small area in the Eisleck. Immediately to the west, in Belgium, it consists of irregular alternations of dark blue phyllites, shales and siltstones with argillaceous sandstone layers and series of sandstones and quartzites of light gray, beige-gray and green-gray colors. Generally, the thicker series of sandstones and quartzites deliver nice outcrops. However, it does not mean that these kinds of rocks are predominant in the formation (Dejonghe, 2013).

Goemaere \& Dejonghe (2005) described the paleoenvironments of this formation at Flamierge, a Belgian locality close to the Belgian-Luxembourgish border. Distinctive sedimentological structures pointed out that the very fine sands, coarse-grained silts and muds are originating from a tidal flat environment. Tidal channels, mud flats, mixed flats and sand flats sub-environments are vertically stacked. 


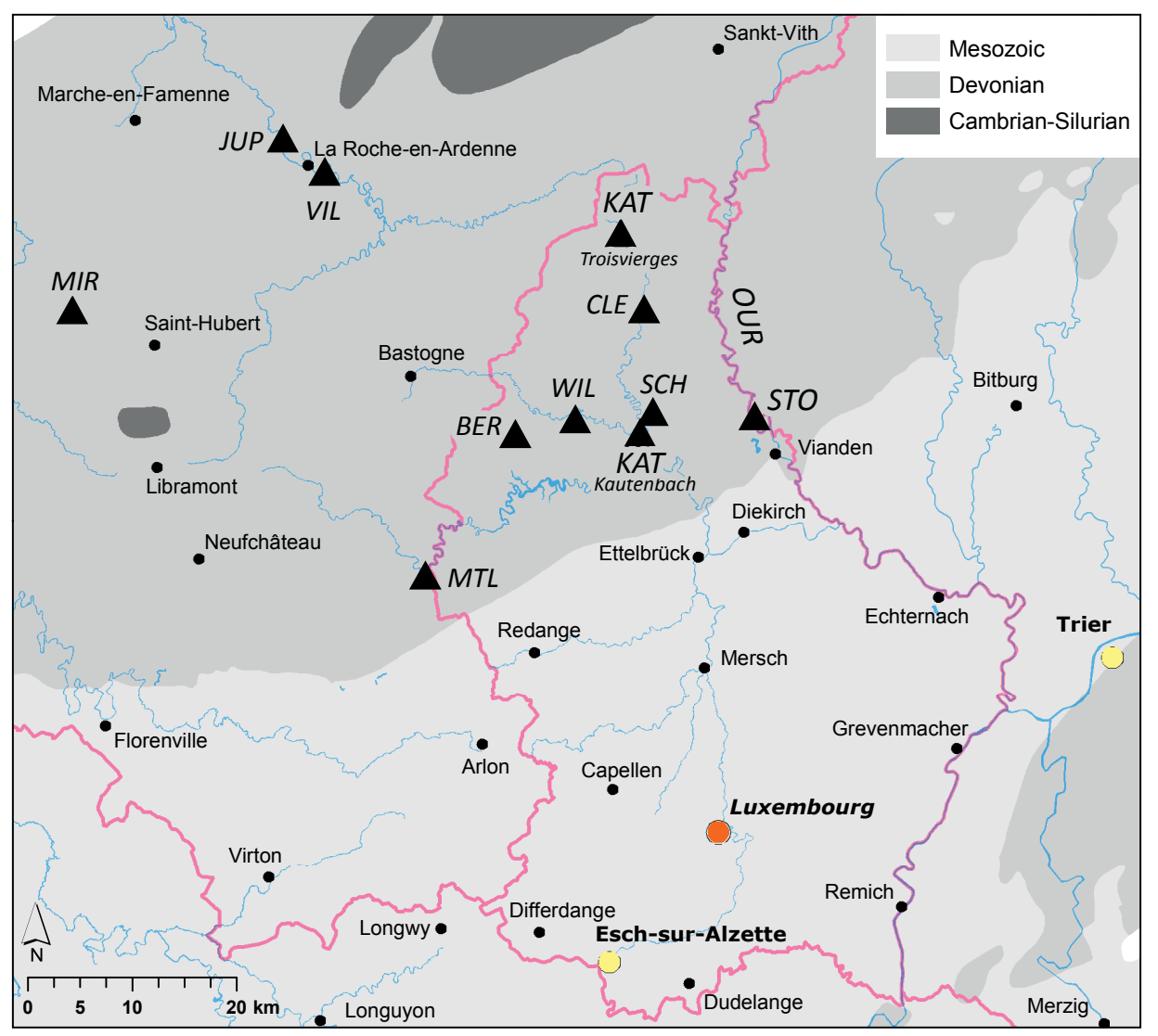

Figure 3. Location map of localities. Triangles with abbreviations correspond to type localities of members and formations. BER $=$ Berlé, CLE $=$ Clervaux, JUP $=$ Jupille, $\mathrm{KAT}=$ KautenbachTroisvierges, $\mathrm{MIR}=$ Mirwart, MTL $=$ Martelange, OUR $=$ River Our, $\mathrm{SCH}=$ Schuttbourg, $\mathrm{STO}=$ Stolzembourg, WIL $=$ Wiltz

Mud/sand flats represented extended surfaces with very low relief areas without any sandy barrier to protect tidal flat from the open sea. These large surfaces are an answer to the transgression over large flood and delta plain flat environments.

The lower boundary of the Mirwart Formation does not appear in Luxembourg. The upper boundary is characterized by a thick series of sandstone and quartzite beds.

\subsection{Villé Formation - VIL}

Type locality situated in Belgium, along the La Roche-enArdenne to Houffalize road (Fig. 3); WGS84 coordinates: 5.59/50.17.

In Belgium, this formation outcrops distinctively between La Roche-en-Ardenne and Houffalize (Dejonghe, 2013). However, its extent is very limited in the north of the Eisleck region, due to the pinching-out of the layers to the northeast. Rock types are very similar to those of the Mirwart, Jupille and Our formations but are characterized by the rather frequent occurrence of fossiliferous sandstone layers (more than 200 different species have been described including crinoids, brachiopods, bivalves, trilobites, tentaculites and corals) (Asselberghs, 1946, pp. 147-157).

In the La Roche-en-Ardenne area, the cement of the fossiliferous sandstones is clearly of carbonate nature (reaction to $0.1 \mathrm{~N} \mathrm{HCl}$ ). At the outcrop, corresponding rocks are generally weathered and are made up of a brownish limonitic residue. Towards the east, the carbonate cement gradually disappears and fossils are diluted in thicker layers (up to a few meters)

Shells were reworked in sand-bearing beds under the action of waves and currents, possibly during storms (tempestites). A Pragian age is assessed by Godefroid et al. (1994).

The Villé Formation has also been named Radelange Formation (d2R) by Colbach (2003) in the geological map sheet no. 7 "Redange". In the absence of good quality outcrops and now that the correspondence to Villé has been established, the Radelange term should be abandoned and only Villé should be used.
The lower boundary of the Villé Formation is defined by the first occurrence of fossiliferous beds more or less carbonated; the upper boundary, by the last occurrence of such beds.

\subsection{Martelange Member - MTL - of the Kautenbach-Trois- vierges Formation}

Type locality of Martelange, a village situated in Belgium, exactly on the Belgian-Luxembourgish border, the corresponding locality on the Luxembourgish side being called Rombach-Martelange (Fig. 3); WGS84 coordinates: $5.73 / 49.83$.

This member, located at the bottom of the KautenbachTroisvierges Formation (KAT), is made up of blue-gray slates which were locally exploited as tiles for roofing and similar purposes in the Martelange - Perlé area and near Asselborn (Emeschbaach) situated some $30 \mathrm{~km}$ further to the north. Foliation cleavage (schistosity) is very pronounced. The member is very lenticular and can locally disappear completely. Geological setting and underground mining of this unit were described by Asselberghs (1924) and Lucius (1947b, 1950).

This member of the Kautenbach-Troisvierges Formation is essentially characterized by blue-gray slates which were locally exploited.

\subsection{Kautenbach-Troisvierges Formation - KAT}

New formation named after Luxembourg localities. Typical outcrops are situated around the Troisvierges railway station and in the Kautenbach hamlet, $5 \mathrm{~km}$ east of Wiltz (Fig. 3); WGS84 coordinates: Kautenbach: 6.016/49.951; Troisvierges: $5.992 / 50.120$.

Gosselet (1885, pp. 283-290) has distinguished the "phyllades de Trois-Vierges" to the north and the "schistes de Kautenbach" to the south, both of "Coblenzian" age (Pragian). Asselberghs (1912, p. M93) referred to the Trois-Vierges and Martelange phyllites of "Siegenian" age (Sg2) (Pragian).

In the Troisvierges area, blue-gray phyllites predominantly occur (Fig. 4). They split into fine sheets that can contain pyrite cubes (up to $1 \mathrm{~cm}$ ). In some places, the phyllites are silty 


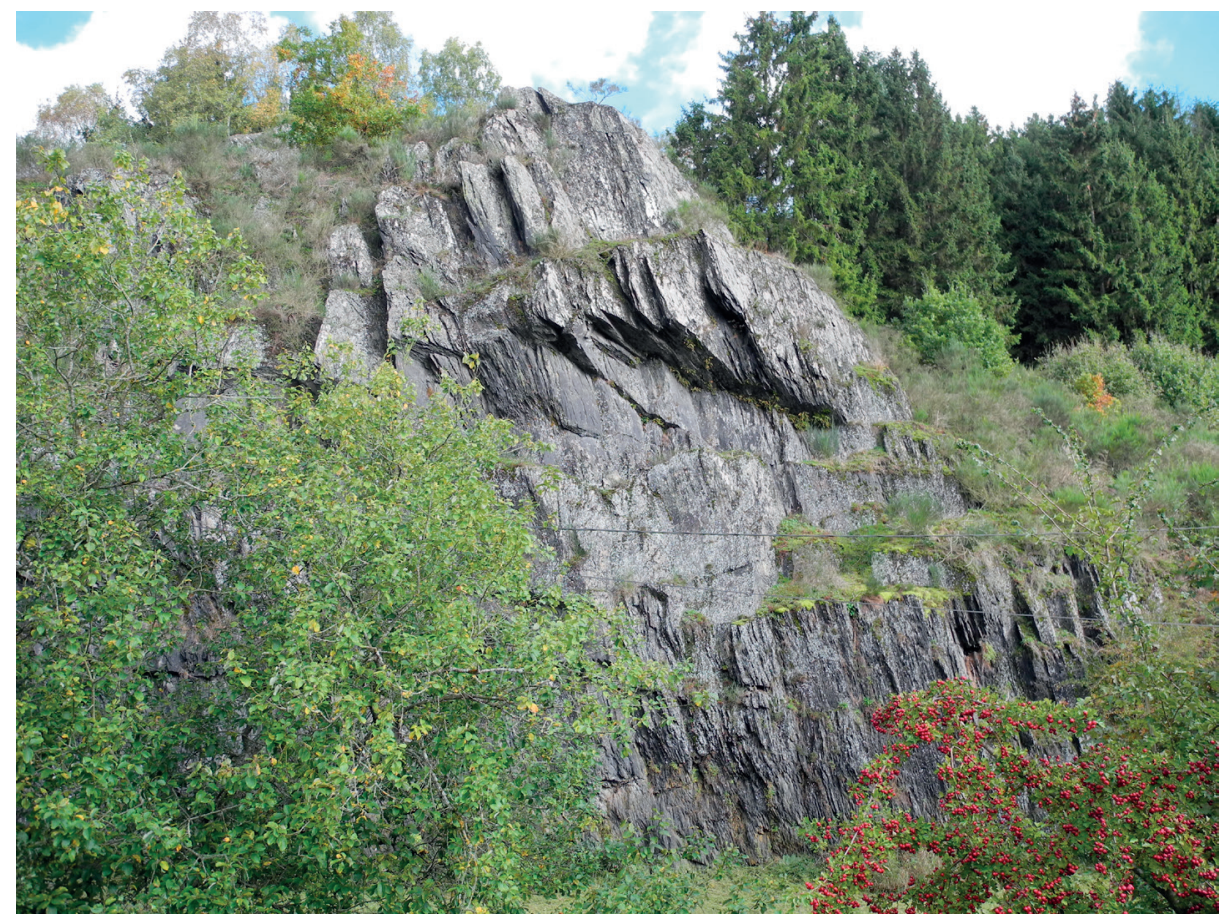

Figure 4. Dark blue-gray phyllites of the Kautenbach-Troisvierges Formation. Troisvierges, railway station.

to sandy and slightly micaceous. Locally, the phyllites contain (occasionally lenticular) beds of light gray or greenish-gray sandstones, sometimes argillaceous and/or slightly micaceous. These sandstone beds are often cut by milky quartz veins which do not extend in the surrounding phyllites. More particular characters may also develop, such as a quartzitic nature, abundant pyrite cubes (mainly in sandstone beds), oblique stratification and wavy bedding. Load casts are rare.

In the Kautenbach area, the blue-gray shales largely outcrop in many different places and reach a total stratigraphic thickness of $1350 \mathrm{~m}$ which is more than in the Troisvierges area. Furthermore, access to these various outcrops is very easy as they do not require any authorization. Blue-gray shales are predominant at the bottom. They may contain light gray sandstone laminae and argillaceous sandstone beds $(10 \mathrm{~cm}$ maximum in thickness $)$ which underline the stratification. The latter are more and more abundant when rising up in the stratigraphic column. Near the top, they can occur as metric series of beds that are often cut by milky quartz veins. The sandy character is thus more pronounced in the Kautenbach area than in the Troisvierges area. Fossils are rare, consisting essentially of brachiopods and bivalves. A Pragian age is likely (Godefroid et al., 1994).

The Kautenbach-Troisvierges Formation is interpreted as a lateral variation of the Laroche Formation under its socalled "St-Vith facies" (see Fig. 2). The St-Vith facies was introduced by Asselberghs (1927, p. 206) who delineated its features in 1946 (pp. 179-186). It is also named Grumelange Formation (d2G) by Colbach (2003) in the geological map sheet no. 7 "Redange", a term that should now be abandoned.

The lower boundary of the Kautenbach-Troisvierges Formation is defined by the occurrence of predominantly blue-gray phyllites overlying fossiliferous beds more or less carbonated of the Ville Formation. The formation is essentially characterized by blue-gray phyllites incorporating sandstone series at the top.

\subsection{Jupille Formation - JUP}

Type locality of Jupille, a small village in Belgium between Hotton and La Roche-en-Ardenne, in the Ourthe valley (Fig. 3); WGS84 coordinates: 5.54/50.21.

The abundance of sandstone beds at the top of the Pragian justified the introduction of the Jupille Formation in eastern Belgium by Dejonghe et al. (2008). This formation, well represented in the Ourthe valley, extends up to Luxembourg, while strongly bevelled in this direction (Fig. 2).
The formation is made up of abundant lenticular beds (a few centimeters or decimeters, sometimes meters thick) of green, blue-green or greenish-gray sandstones, sometimes laminar and also sometimes argillaceous. A limonitic alteration in the periphery of the fractured blocks is common. Occasionally, beds are gathered in several meters thick series forming large outcrops which have frequently been mined. Sandstone beds are interlayered with blue-gray siltstones and phyllites similar to those of the La Roche and KautenbachTroisvierges formations. Gray micaceous sandstones with tool marks, current ripples, lenticular and oblique stratifications and wavy bedding also occur. Load cast up to $50 \mathrm{~cm}$ long have been observed. All intermediate rocks between pure sandstones and pure quartzite do exist. The cement of the rock can also be very slightly carbonated. Fossils were described by Asselberghs (1946, pp. 181-184). The Pèrnelle Formation, which is situated above the Jupille Formation in Belgium, is comprised in the palynological biozone $\mathrm{Su}$ in the uppermost Pragian or lowermost Emsian (Steemans, 1989; Streel et al., 2000). This datum gives a stratigraphical constraint to the Jupille Formation (see Table 1).

If a thickness of around $1500 \mathrm{~m}$ is attributed to the Kautenbach-Troisvierges Formation, and due to the inclination of the fold axes of about $10^{\circ}$ towards the NE, the rocks situated in the Lengeler region (Belgium) and the north of the Eisleck belong either to the top of the KautenbachTroisvierges Fm or to the Jupille Fm, which has a very reduced thickness in Luxembourg. Although palynological investigations by $\mathrm{Ph}$. Steemans on 12 different samples did not succeed in dating these rocks, Dejonghe (2015) suggested an attribution of the rocks in the northernmost part of the Eisleck to the Jupille Formation.

Shortly, the Jupille Formation is made up of abundant lenticular sandstone beds interlayered with blue-gray siltstones and phyllites similar to those of the Kautenbach-Troisvierges Formation.

\subsection{Our Formation - OUR, Stolzembourg Member - STO and Schuttbourg Member - SCH}

Our is a new formation named after the Our river and valley on the German-Luxembourgish border, where relevant rocks widely outcrop; Stolzembourg is a village in the Our valley; Schuttbourg is a castle in the Clerve valley north of Kautenbach; both are situated in Luxembourg (Fig. 3); WGS84 coordinates: Stolzembourg: 6.166/49.965; Schuttbourg: 6.026/49.965. 
Gosselet (1885, pp. 276-283) introduced the notions of "quartzophyllades de Heinerscheid" to the north of the Eisleck and "quartzophyllades de Schuttbourg" to the south. He considered that the "quartzophyllades de Schuttbourg" were directly situated above the Kautenbach shales. Asselberghs (1912, p. M93) used a comparable terminology for the Emsian Em1. Later, Lucius $(1949,1950)$ distinguished, at the bottom, the "schistes de Stolzembourg" and, at the top, the "quartzophyllades de Schuttbourg". Furtak (1965) grouped both units in a single series labelled "C complex" (see Table 1).

For Lucius (1949, 1950), clear petrographic differences between the bottom and the top of this series justified the subdivision into two parts. He stated that:

In the lower part (E1a), corresponding to the "schistes de Stolzembourg", shales, phyllites and mixed quartzite and phyllites of dark colors are prevailing and show intercalations of thin and rare quartzitic sandstones. Stratification is nearly completely wiped away by the foliation (schistosity);

In the upper part (E1b) forming the "quartzophyllades de Schuttbourg", stratification is very clear due to the presence of thick beds of quartzitic sandstones that are frequently intercalated in the shales and phyllites.

Even if we recognize that the lower part of this series significantly differs from the upper part, Lucius's subdivision $(1949,1950)$ cannot be easily applied in the field as lithologic variations are progressive. Subsequently, an accurate stratigraphic limit materialized by a clear marker bed cannot be defined. Lucius's subdivisions should be considered as facies variations within the Our Formation. This point of view is shared by Furtak (1965) and Muller (1980, pp. 586-587). Konrad \& Wachsmut (1973) are going even further, considering that limits cannot be placed between the KautenbachTroisvierges Formation, the Stolzembourg Member and the Schuttbourg Member and that they all should be grouped into a single unit. In this paper, we adopt the views of Furtak (1965) and Muller (1980). In order to facilitate the lecture of older works, we suggest subdividing the Our Formation into two members (Stolzembourg and Schuttbourg), while we believe this limit between the two members is very subjective due to the progressive variation in lithology.

In the Stolzembourg Member, the argillaceous nature of the rock is predominant. Rocks are silty to sandy and consist of dark gray or dark blue-gray shales or coarse-grained phyllites. Shales and phyllites pass imperceptibly into argillaceous and weakly micaceous dark gray and dark blue-gray sandstones. Occasionally, very compact sandstones with a thickness of a few $\mathrm{cm}$ to a few $\mathrm{dm}$ occur. Current ripples and load casts (Fig. 5) may be observed.

In the Schuttbourg Member, shales and phyllites incorporate frequent sandstone and quartzite beds, with thicknesses often between 10 and $30 \mathrm{~cm}$. Beds are isolated or grouped in sets reaching more than $20 \mathrm{~m}$ in thickness, and then usually mined in quarries (Heinerscheid, Lieler, Sassel, Weiswampach, Consthum, etc.). This rock type is locally referred to as "Hasselt". The colors of the sandstones are mostly gray to greenish and significantly clearer than those of the surrounding shales and phyllites. Sandstones become darker and darker with an increasing argillaceous and micaceous content. In some places, laminar textures, and even ribbon texture, occur (in the latter case, the rock consists of a mixture of alternating gray sandstones and dark gray argillaceous sandstones, a rock type usually referred to as "quartzophyllade" by former authors). Undulating joints (current ripples) are present but rare. Beds are usually limited by planar surfaces. They are sometimes lenticular. Load cast were observed at various stratigraphic levels. The thickest beds of sandstones are usually crossed by milky quartz veins. But no boudinage was observed (competent beds between less competent layers are not streched, thinned and broken at regular intervals into bodies resembling boudins or sausages).

The load casts (also called pseudonodules) of the Our Formation were described by Macar \& Antun (1950). They are present at various stratigraphic levels in both members of the Our Formation, but with a greater abundance in the Stolzembourg Member. Their distribution is erratic and a correlation between the different levels is difficult to establish. However, they remain useful structures in order to assess the polarity of the beds.

Most of the rocks are non-fossiliferous. Fossils were however described by Asselberghs (1932, p. 5) in the vicinity of the Schuttbourg castle. Furthermore, Basse \& Franke (2006) have studied two fossiliferous sites (Buregronn and Reidesbaach near Heiderscheid) that have yielded a rich and well preserved fauna of marine benthic invertebrates. Most striking features of these beds are the high number (11) of trilobite taxa identified for the first time in Luxembourg. The occurrence of some exotic fenestellids is also worth mentioning. Basse \& Franke established a very early Emsian age for the Reidesbaach site. The beds of the Buregronn site
Figure 5. Gray sandstone bed overlaid by a level rich in load casts, Our Formation. Stubach, Our valley.

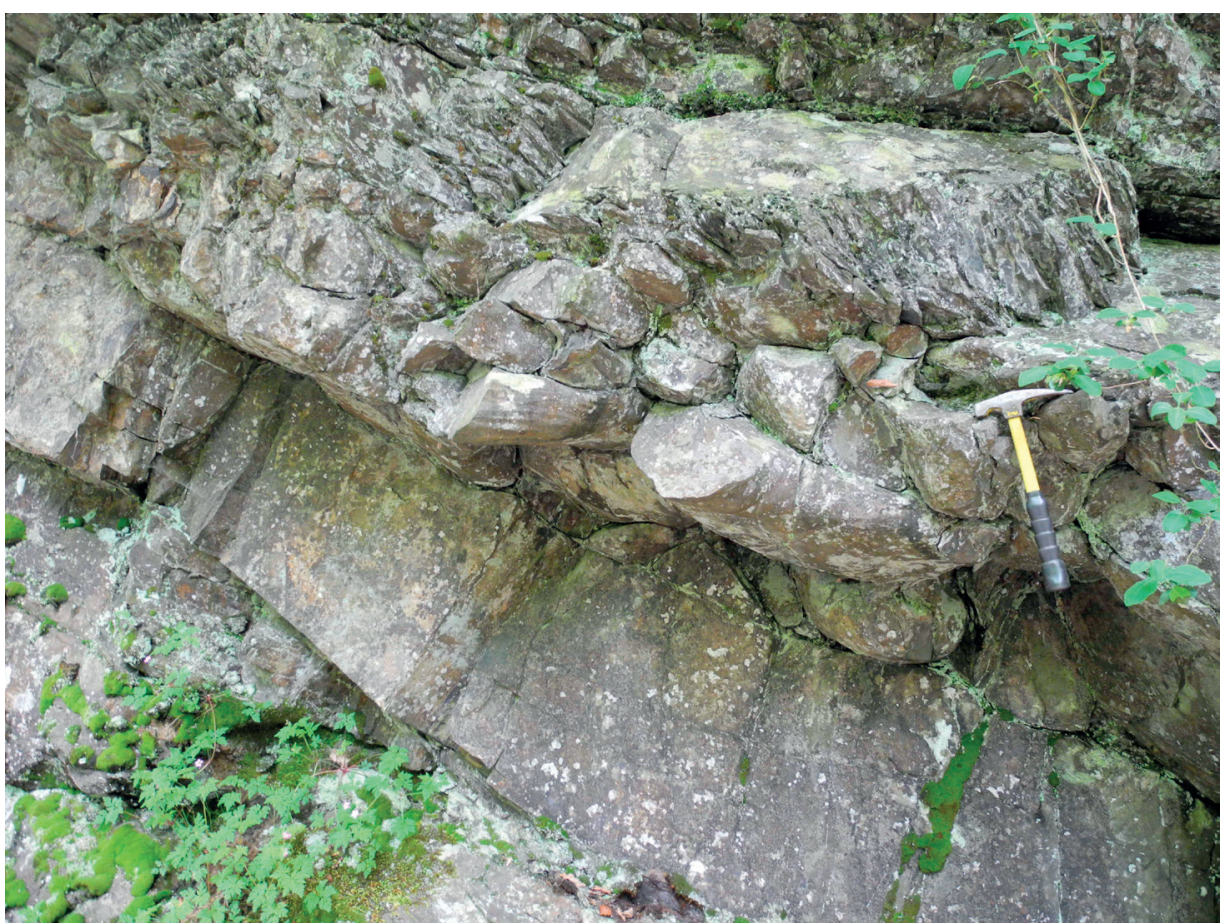


are slightly older than Reidesbaach and have yielded a small and fairly different trilobite fauna. Poschmann \& Franke (2006) detailed fossils found in the Merkholtz and Consthum quarries. Immediately to the North of the Eisleck border, in Burg-Reuland (Belgium), De Baets et al. (2013) have identified ammonoids in the Our Formation which confirm the marine character of the formation at this place and infer a lower Emsian age (Singhofen or Vallendar, in the German sense).

Based on fresh outcrops during the digging of the trenches of the E42 highway, Vandenven (1990) suggested the name "Breitfeld-Steinebrück Formation" for the Our Formation. Unfortunately, at present, outcrops have disappeared or are strongly covered by vegetation. Therefore, this name is unused and abandoned.

To indicate a lower boundary for the Our Formation is a case of wishful thinking as variations in lithology are progressive. This formation is essentially made up of dark blue-gray shales or coarse-grained phyllites that incorporate frequent sandstone and quartzite beds more and more abundant towards the top. The upper boundary is placed below the first variegated and/or pale green beds of the Clervaux Formation.

\subsection{Clervaux Formation - CLE}

Type locality of Clervaux, Grand-Duchy of Luxembourg (Fig. 3); WGS84 coordinates: 6.03/50.05.

The name is due to Gosselet (1885, pp. 269-276) who mentioned the "schistes rouges de Clervaux". It is indeed the color which is the characteristic feature of this formation. The rocks are made up of a mixture of light gray, light green or pale olive-green (predominant feature) and variegated (red and green) shales in which sandstones and quartzite are intercalated. Sandstones display different colors (dark green, bluish, rarely red). They are either coarse-grained or finegrained and often micaceous. Quartzites are generally whitishgray. The pale green shales show a soft talc touch. Lithologic variations are rapid and likely due to sedimentation zone variations (marine, coastal and continental).

Asselberghs (1932, p. 9) considered that the Clervaux beds corresponded to a regression. However, in 1941, he stated more precisely that the maximum of regression occurred in the lower part of the Clervaux shales of middle Emsian age. Then a transgression started in the middle Emsian and continued up to the end of the Clervaux period and later on, during the upper Emsian, with the deposition of the Berlé Quartzite and the Wiltz shales (Asselberghs, 1941, p. 78). Franke (2006b) attempted to document and to establish the character of the Clervaux beds as a river dominated delta by means of facies studies. He interpreted the simultaneously deposited fauna of the stagnant water area within the delta plain and the marine shallow water fauna at the delta front and further in the prodelta as well as in reoccupied areas with pioneer populations. The assumption of a dawning estuary is very likely during this time and confirmed by Michel et al. (2010). They conducted a sedimentological study using facies analysis and magnetic susceptibility of beds of the Clervaux Formation in the Wiltz Synclinorium (Himmelbaach quarry). They put forward a tide-dominated marginal-marine depositional model composed of three facies, respectively: tidal channels, tidal flat and tidal sand ridge. Fossils are scarce in the Clervaux Formation. However, a fossiliferous deposit near Wiltz allowed Asselberghs (1941, pp. 75-78) to determine an Emsian age for this formation. Franke (2006b) identified characteristic marine and continental Emsian fauna.

We have to mention that some confusion may arise if we compare the different stratigraphic views concerning the Clervaux Formation in Luxembourg and in Germany even if we know that a formation can be diachronous and can vary laterally in thickness. For the German authors, the "Klerfer Schichten", the "Klerf Schichten" or the "KlerfFormation" do not correspond to the same stratigraphic level as for the Clervaux Formation ("Klerf Formation") used in
Luxembourg (see e.g., Landesamt für Geologie und Bergbau Rheiland-Pfalz, 2005, pp. 36-39; Ribbert, 2008, p. 288, or, for a larger comment, Franke, 2006b, pp. 54-57). The German meaning is summarized in the Lithostratigraphische Einheiten Deutschlands (Ribbert, 2007) . Indeed, in Germany, the "Klerf Formation" corresponds to a much larger part of the Emsian and thus also includes the time span of the Our Formation. As the term "schistes rouges de Clervaux" was introduced by Gosselet in 1885, the use of this term in its original meaning benefits from a clear priority. The use of the same locality name for two different stratigraphic units has to be considered as a misapprehension by the German authors, even if they considered that the two corresponding series have the same facies.

The lower boundary of the Clervaux Formation corresponds to the first occurrence of variegated and/or pale green beds; the upper boundary, to the last variegated and/or pale green beds.

\subsection{Berlé Quartzite Member - BER}

The Berle Member is situated at the top of the Clervaux Formation or at the bottom of the Wiltz Formation (Berlé is a small village situated between Bastogne and Wiltz in the Grand-Duchy of Luxembourg (Fig. 3); WGS84 coordinates: 5.857/49.952).

The term was first used by Gosselet (1885) who mentioned the "quartzites (plural) de Berle". The rock typically is a white quartzite, occurring in massive beds ranging in thickness from a few decimeters to a few meters, separated by shale interlayers. Its stratigraphic position was discussed by Asselberghs (1932, p. 6 and pp. 14-15) and by Lucius (1950, p. 21). It was sometimes placed at the top of the middle Emsian (in the Clervaux Formation, e.g. by Asselberghs, 1932; Lucius, 1947a,b; Muller, 1980) and sometimes at the bottom of upper Emsian (at the bottom of the Wiltz Formation, e.g. by Gosselet, 1885; Lucius, 1950). Minten (1997) considers it as a diachronous level at the same time at the top of the Clervaux Formation and at the bottom of the Wiltz Formation. Either way, the Berlé Quartzite is a very good marker level at the limit between middle and upper Emsian.

Michel (2012) put forward a model in which the Berlé Quartzite corresponds to tidal sand ridges and laterally changes into the flaser-bedded sandstones of the top of the Clervaux Formation. This lateral facies transition tends to proof that the Berlé Quartzite is a lenticular deposit. It is an outstanding landscape feature and a very resistant rock appreciated as building stone and for its refractory qualities. The measurement of the illite cristallinity index showed that the Berlé Quartzite underwent variable conditions of burial, depending of the area considered. The quartzite contains numerous fossil molds (mainly bivalves), described by Asselberghs (1946, pp. 261-265), Lucius (1950, pp. 60-61) and Franke (2016). beds

Shortly, the Berlé Member is a level of white quartzite

\subsection{Wiltz Formation - WIL}

Type locality of Wiltz, Grand-Duchy of Luxembourg (Fig. 3). Gosselet (1885) spoke about "schistes de Wiltz". WGS84 coordinates: 5.93/49.96.

The Wiltz Formation is made up of blue, green or dark green shales (either fine-grained or coarse-grained), sometimes micaceous. Relatively rare thin sandstone layers are occasionally interbedded in the shales. The shales contain numerous fine-grained sandstone nodules. Muller (1980, p. 587) also mentions the occurrence of spherosiderite concretions. Fossiliferous beds (mainly brachiopods, trilobites, orthoceratidae) very rich in Spirifer arduennensis are frequent, mainly in the lower part of the formation (Asselberghs, 1946) (Fig. 6). A detailed list of fossils is given by Lucius (1950, pp. 60-61). Plusquellec et al. (2016) described new hyostragulids and Plusquellec \& Franke (2016), a rich fauna 


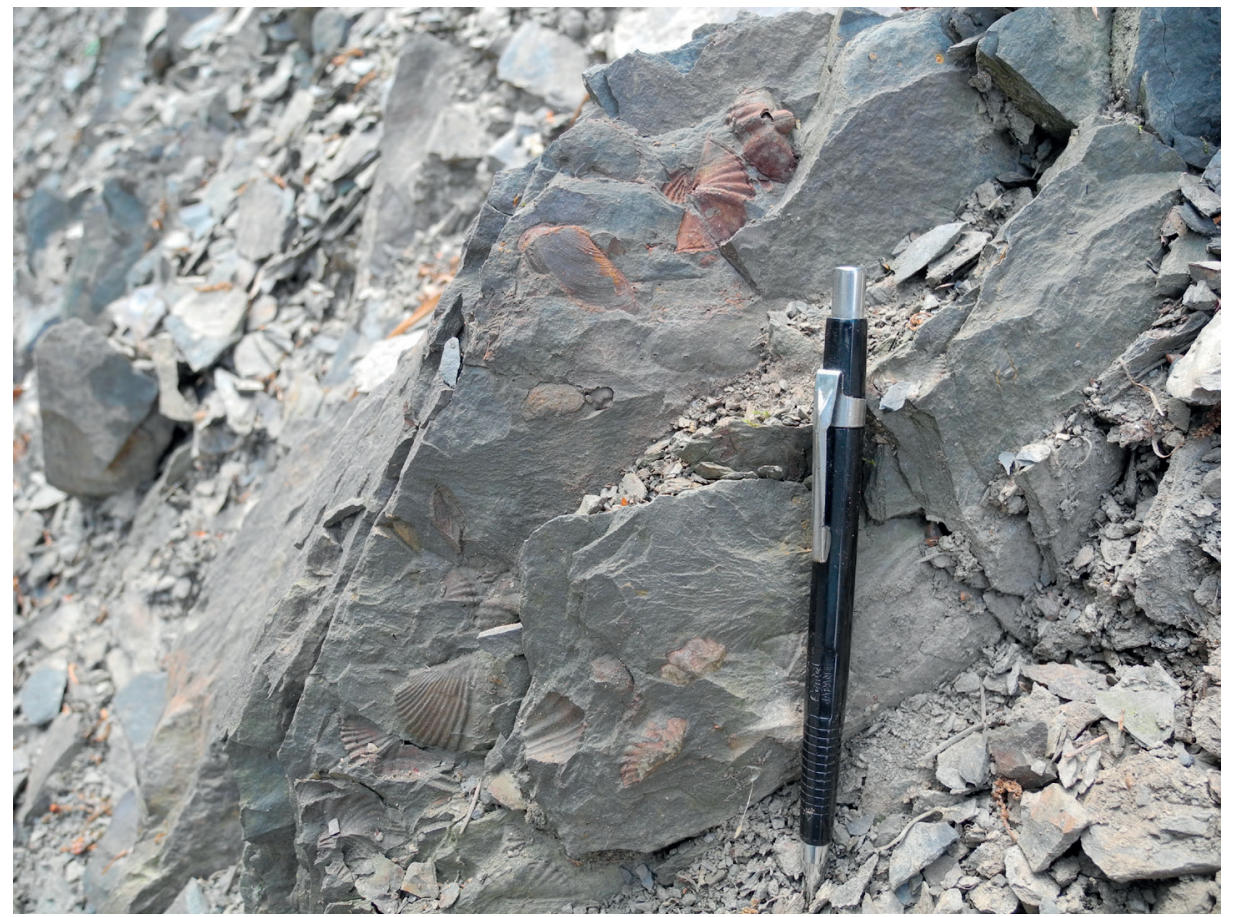

Figure 6. Fossiliferous gray argillaceous sandstone bed of the Wiltz Formation. Some fossils are slightly limonitic. Bockholtz, Kazebësch, C.R. 324 road.

of Pleurodictyum-like corals. Stratification is usually difficult to recognize due to a very strong foliation (schistosity). The sandstone nodules are indeed generally elongated, reaching a length of over $15 \mathrm{~cm}$ and are reoriented in the foliation planes (Asselberghs, 1932, p. 9; Muller, 1980, p. 587).

The Wiltz Formation is mainly made up of blue, green or dark green shales with sandstone nodules and relatively rare interbedded thin sandstone layers. Fossils are frequent. The lower boundary corresponds to the first blue, green or dark green shales overlying the last variegated and/or pale green beds of the Clervaux Formation. The upper boundary is not exposed in Luxembourg.

\section{Thicknesses of the formations}

Thicknesses of the various formations of the lower Devonian in the Ardennes region are presented in Table 2. Data are compiled from Asselberghs (1946, p. 189, p. 224, p. 250, p.
275), Lucius (1950, p. 21), Konrad \& Wachsmut (1973, pp. 4-6), Furtak (1965, p. 287, pp. 290-292), Minten (1997) and Bultynck \& Dejonghe (2001, pp. 42-44).

Asselberghs (1946, p. 357) mentions that, according to Fourmarier, the maximum thickness of the lower Devonian is $9000 \mathrm{~m}$ in the Neufchâteau Synclinorium. However, his assessment is more moderate and the figure that he advances is roughly half of Fourmarier's. On pages 361-367 and in plate 4 of his annexes, he discusses the variations of thickness for the lower Devonian in Belgium and adjacent countries. A general trend shows an increase of thicknesses from north to south up to the central part of the Neufchâteau basin. More to the south of this area, thicknesses would decrease, which allows concluding to a high in this direction. Lucius (1950) conforms to Asselberghs (1946) data. Thicknesses of the various formations are considered higher by Konrad \& Wachsmut (1973) and even significantly higher by Furtak (1965). Indeed, Furtak's

\begin{tabular}{|c|c|c|c|c|c|c|c|c|}
\hline $\begin{array}{l}\text { Formations } \\
\text { (2016) } \\
\text { Eisleck }\end{array}$ & $\begin{array}{c}\text { Asselberghs } \\
\quad(1946) \\
\text { Neufchâteau } \\
\text { Synclinorium }\end{array}$ & $\begin{array}{l}\text { Lucius } \\
(1950) \\
\text { Eisleck }\end{array}$ & $\begin{array}{c}\text { Konrad \& } \\
\text { Wachsmut } \\
\text { (1973) } \\
\text { South } \\
\text { Eisleck }\end{array}$ & $\begin{array}{l}\text { Furtak } \\
(1965) \\
\text { Eisleck } \\
\text { s.l. }\end{array}$ & $\begin{array}{c}\text { Minten } \\
(1997) \\
\text { SW } \\
\text { Eisleck }\end{array}$ & $\begin{array}{c}\text { Dejonghe } \\
\text { (2015) } \\
\text { Troisvierges } \\
\text { and } \\
\text { Clervaux } \\
\text { sheets }\end{array}$ & $\begin{array}{c}\text { Bultynck } \\
\& \\
\text { Dejonghe } \\
\text { (2001) } \\
\text { Dinant } \\
\text { Nappe }\end{array}$ & $\begin{array}{l}\text { Formations } \\
\text { (2001) } \\
\text { Belgium }\end{array}$ \\
\hline Wiltz & \pm 150 & \pm 250 & 200 & \multirow{3}{*}{$\begin{array}{l}400- \\
1400\end{array}$} & $>250$ & & $160-330$ & Hierges \\
\hline Berlé & $0-30$ & $\begin{array}{l}2-5 \text { to } \\
10-15\end{array}$ & $<15$ & & $10-15$ & & & \\
\hline Clervaux & $20-400$ & $\begin{array}{c}200- \\
400 \\
\end{array}$ & 600 & & 400 & & $320-800$ & Chooz \\
\hline $\begin{array}{c}\text { Our } \\
\text { (Schuttbourg) }\end{array}$ & \multirow{2}{*}{750} & \multirow{2}{*}{750} & \multirow{4}{*}{3500} & \multirow{2}{*}{$\begin{array}{c}2800- \\
6000\end{array}$} & $\begin{array}{c}500- \\
600\end{array}$ & \multirow{2}{*}{2500} & $80-400$ & Vireux \\
\hline $\begin{array}{c}\text { Our } \\
\text { (Stolzembourg) }\end{array}$ & & & & & \pm 500 & & $160-800$ & Pesche \\
\hline Jupille & \multirow{2}{*}{$400-1500$} & \multirow{2}{*}{$\begin{array}{l}500- \\
1500\end{array}$} & & \multirow{2}{*}{$\begin{array}{c}3300- \\
3700\end{array}$} & \multirow{2}{*}{1500} & 250 & $<1000$ & $\begin{array}{l}\text { Jupille + } \\
\text { Pèrnelle }\end{array}$ \\
\hline $\begin{array}{l}\text { Kautenbach- } \\
\text { Troisvierges }\end{array}$ & & & & & & $1350-1500$ & $215->800$ & La Roche \\
\hline Villé & $400-500$ & & & \multirow{2}{*}{$\begin{array}{l}2200- \\
2700\end{array}$} & 400 & & $30-300$ & Villé \\
\hline Mirwart & $650-1000$ & & & & & & $300-1000$ & Mirwart \\
\hline Total (m) & $2220-4330$ & $\begin{array}{l}1702- \\
2915\end{array}$ & 4315 & $\begin{array}{l}8700- \\
13,800\end{array}$ & 3665 & & $\begin{array}{l}1265- \\
5430\end{array}$ & Total (m) \\
\hline
\end{tabular}

Table 2. Thicknesses (in meters) of the lower Devonian formations in Belgium and in Luxembourg. 
figures are in average two to three times higher than those of Asselberghs and Lucius. Nevertheless, Furtak pointed out these figures on the basis of detailed cross-sections. Dejonghe's data for the north of the Eisleck are in the range of those of Asselberghs, Lucius and Konrad \& Wachsmut (op. cit.).

\section{Conclusions}

In order to allow modern geological mapping of the Eisleck area, a lithological framework (based on detailed field mapping of the sheets Troisvierges and Clervaux) is proposed. Seven formations are considered and their lithological characteristics, thicknesses and paleogeographical settings are described. References to their paleontological content are also mentioned.

Detailed geological mapping printed at the scale 1 to 25,000 , with field survey at the scale 1 to 10,000 , started in Wallonia in 1990. It was documented by Bellière et al. (2007). Further information may be found on the website at the address: http://geologie.wallonie.be/.

It should be required that national borders did not prevent geological correlations between different countries. The present contribution aims at providing a useful lithostratigraphic framework for the geological mapping in the Eisleck region and aims at helping cartographers involved with border maps between Belgium and Luxembourg to harmonize their drawings. Indeed, formations existing at both sides of the border are correlated.

\section{Acknowledgments}

The authors are indebted to the three reviewers, Karl-Heinz Ribbert (Geological Survey of North Rhine-Westphalia, Krefeld, Germany), Martin Salamon (Geological Survey of North Rhine-Westphalia, Krefeld, Germany) and Phillippe Steemans (Liège University, Belgium), for their interesting comments and suggestions. The useful remarks of Annick Anceau (Executive editor of Geologica Belgica) were also appreciated.

\section{References}

Asselberghs, E., 1912. Contribution à l'étude du Dévonien inférieur du Grand-Duché de Luxembourg. Annales de la Société géologique de Belgique, 39, M25-M112.

Asselberghs, E., 1913. Le Dévonien inférieur du bassin de l'Eifel et de l'anticlinal de Givonne dans la région sud-est de l'Ardenne belge. Mémoires de l'Institut géologique de l'Université de Louvain, 1 , $1-175$.

Asselberghs, E., 1924. Les ardoisières du Dévonien de l'Ardenne. Annales des Mines de Belgique, 25, 1037-1098.

Asselberghs, E., 1927. Siegenien, Siegenerschichten, Hunsruckschiefer et Taunusquarzit. Bulletin de la Société belge de Géologie, de Paléontologie et d'Hydrologie, 36(1926), 206-222.

Asselberghs, E., 1932. Le Dévonien inférieur de la Prusse Rhénane à l'Ouest des bassins calcaires de l'Eifel. Mémoires de l'Institut géologique de l'Université de Louvain, 5, 1-46.

Asselberghs, E., 1941. Emsien et Koblenzschichten en Ardenne, dans l'Oesling et dans l'Eifel. Mémoires de l'Institut géologique de Louvain, 13, 63-86.

Asselberghs, E. 1946. L'Eodévonien de l'Ardenne et des régions voisines. Mémoires de l'Institut géologique de l'Université de Louvain, 14, 1-598.

Asselberghs, E. \& Leblanc, E., 1934. Le Dévonien inférieur du Bassin de Laroche. Mémoires de l'Institut géologique de l'Université de Louvain, 8, 1-79.

Basse, M. \& Franke, C., 2006. Marine Faunen aus dem frühen Unteremsium (Unterdevon) des Givonne-Oesling Antiklinoriums (Luxemburg). Ferrantia, 46, 7-41.

Bellière, J., Boulvain, F., Dejonghe, L., Delmer, A., Laloux, M. \& Poty, E., 2007. La carte géologique de Wallonie. Comité de l'Académie pour les Applications de la Science, Académie royale des Sciences, des Lettres et des Beaux-Arts de Belgique, Bruxelles, $12 \mathrm{p}$.

Bultynck, P. \& Dejonghe, L., 2001. Devonian lithostratigraphic units (Belgium). In : Bultynck \& Dejonghe (eds), Guide to a revised lithostratigraphic scale of Belgium. Geologica Belgica, 4/1-2, 39-69
Colbach, R., 2003. Carte géologique du Luxembourg, feuille $\mathrm{N}^{\circ} 7$, Redange à l'échelle de 1/25 000. Service géologique, Ministère des travaux publics, Luxembourg.

De Baets, K., Goolaerts, S., Jansen, U., Rietbergen, T. \& Klug, C., 2013. The first record of Early Devonian ammonoids from Belgium and their stratigraphic significance. Geologica Belgica, 16/3, 148-156.

Dejonghe, L. 2013. Geology of the Ardenne Anticlinorium, in the Amberloup - La Roche-en-Ardenne - Houffalize sector. The faults of the La Roche Syncline and the overturned Taverneux Anticline. Geologica Belgica, 16/3, 196-205.

Dejonghe, L., 2015. Carte géologique du Luxembourg, feuille $\mathrm{N}^{\circ} 1$, Troisvierges à l'échelle de 1/25 000 avec notice explicative. Service géologique de l'Etat, Administration des ponts et chaussées, Luxembourg, submitted.

Dejonghe, L., Dumoulin, V. \& Blockmans, S., 2008. La Formation de Jupille, nouvelle formation dans le Dévonien inférieur de la Haute-Ardenne (Belgique). Geologica Belgica, 11,71-81.

Franke, C. (ed.), 2006a. Beiträge zur Paläontologie des Undervons Luxemburgs (1). Ferrantia, 46, 1-115.

Franke, C., 2006b. Die Klerf-Schichten (Unter-Devon) im Großherzogtum Luxemburg, in der Westeifel (Deutschland) und im Gebiet von Burg Reuland (Belgien): fazielle und biostratigraphische Deutungen. Ferrantia, 46, 42-96.

Franke, C., 2016. Die Fauna der Berlé-Quartzite in Luxemburg und WestEifel. Ferrantia, 73, 5-110.

Fuchs, G. 1989. Die unterdevonische Schictenfolge bei Neuerburg in der Weisteifel. Mainzer geowissenschaftliche Mitteilungen, 18, 103-124.

Furtak, H., 1965. Die Tektonik der unterdevonischen Gesteinsfolge im deutsch-belgisch-luxemburgischen Grenzgebiet. Geologische Mitteilungen Aachen, 4/3, 273-332.

Godefroid, J., Blieck, A., Bultynck, P., Dejonghe, L., Gerrienne, P., Hance, L., Meilliez, F., Stainier, P. \& Steemans, P., 1994. Les formations du Dévonien inférieur du Massif de la Vesdre, de la Fenêtre de Theux et du Synclinorium de Dinant (Belgique, France). Mémoires pour servir à l'Explication des Cartes géologiques et minières de la Belgique, 38, 1-144.

Goemaere, E. \& Dejonghe, L., 2005. Paleoenvironmental reconstruction of the Mirwart Formation (Pragian) in the Lambert Quarry (Flamierge, Belgium). Geologica Belgica, 8/3, 37-52.

Gosselet, J., 1885. Aperçu géologique sur le terrain dévonien du Grand-Duché de Luxembourg. Annales de la Société géologique du Nord, 12, 260-300.

Hedberg, H., 1976 (ed.). International stratigraphic guide: a guide to stratigraphic classification, terminology and procedure. John Wiley, New York, 200 p.

Konrad, H.J. \& Wachsmut, 1973. Zur lithologie und Tektonik des Underdevons im südlichen Oesling Luxemburgs. Publications du Service géologique du Luxembourg, Bulletin 5/1973, 1-20.

Kräusel, R. \& Weyland, H., 1930. Die Flora des deutschen Unterdevons. Abhandlungen Preussisches geologisches Landesanstalt, 131, 1-92.

Landesamt für Geologie und Bergbau Rheiland-Pfalz (ed.), 2005. Geologie von Rheinland-Pfalz. Schweizerbart'sche, Stuttgart, 400 p.

Leblanc, Ed., 1923. Le contour oriental de l'anticlinal de Bastogne et ses relations avec le flanc sud de l'anticlinal de Stavelot. Mémoires de l'Institut géologique de l'Université de Louvain, 2 (1921-1923), 287-399.

Lippert, H., 1937. Unterkoblenz-Fundpunkte in Norden and Western der Sötenicher Mulde. Seckenbergiana, 19, 282-288.

Lippert, H., 1939. Geologie der Daleider Mulden-Gruppe. Abhandlungen der Seckenbergischen Naturforschende Gesellschaft, 445, 1-66.

Lucius, M., 1913. Die Tektonik des Devons im Grossherzogtum Luxemburg. Mitteilungen der Gesellschaft Luxemburger Naturfreunde, 1-104.

Lucius, M., 1937. Die Geologie Luxemburgs in ihren Beziehungen zu den benachbarten Gebieten. Publications du Service de la Carte géologique du Luxembourg, 1, 1-176.

Lucius, M., 1940. Die Entwicklung der geologischen Erforschung Luxemburgs (Erster Teil). Publications du Service géologique de Luxembourg, 2, 5-257.

Lucius, M., 1947a. La terre luxembourgeoise. In : Le Luxembourg, Livre du Centenaire, 509-563.

Lucius, M., 1947b. La géologie de nos ardoisières. Revue technique luxembourgeoise, $39^{\mathrm{e}}$ année, 2, 96-112.

Lucius, M., 1949. Carte géologique du Luxembourg. Feuille No8 Wiltz à 1 : 50 000. Service géologique, Ministère des travaux publics, Luxembourg.

Lucius, M., 1950. Das Oesling. Erläuterungen zur geologischen Spezialkarte Luxemburgs. Publications du Service géologique de Luxembourg, 6, 1-175. 
Lucius, M., 1955. Les traits fondamentaux de l'allure tectonique du Dévonien de l'Oesling. Bulletin de la Société des Naturalistes Luxembourgeois, 59, 17-50.

Macar, P. \& Antun, P., 1950. Pseudo-nodules et glissements sousaquatiques dans l'Emsien inférieur de l'Oesling (G.D. de Luxembourg). Annales de la Société géologique de Belgique, 73, B121-B150.

Michel, J. 2012. Lithostratigraphie, sédimentologie et analyse séquentielle du Quartzite de Berlé (Emsien supérieur, GrandDuché de Luxembourg).Unpublished PhD thesis. University of Liège, $209 \mathrm{p}$.

Michel, J., Boulvain, F., Philippo, S. \& Da Silva, A.C., 2010. Palaeoenvironmental study and small-scale correlations using facies analysis and magnetic susceptibility of the Mid-Emsian (Himmelbaach quarry, Luxembourg). Geologica Belgica, 13/4, 447458.

Minten, V., 1997. Les formations du Dévonien inférieur de l'Ardenne luxembourgeoise. Unpublished report. Service géologique du Luxembourg, $16 \mathrm{p}$.

Mosar, J., 1987. Schistosité et métamorphisme hercyniens dans les Ardennes luxembourgeoises. Sciences Géologiques. Bulletin, 40/3, 231-243.

Muller, A., 1980. Luxembourg. In Lorenz C. (ed.), Géologie des pays européens: France, Belgique, Luxembourg. Dunod, Paris, 577594.

Plusquellec, Y. \& Franke, C., 2016. Pleurodictyformes (Cnidaria, Tabulata) des Couches de Wiltz, Emsien supérieur, de l'Eifel occidental (Luxembourg, Allemagne). Ferrantia, 73, 127-153.

Plusquellec, Y., Galle, A. \& Franke, C., 2016. New hyostragulids, Tabulata incertae sedis from the Wiltz-beds, Upper Emsian of Western Eifel (Germany). Ferrantia, 73, 111-126.

Poschmann, M. \& Franke, C., 2006. Arthropods and trace fossils from the Lower Devonian (Emsian) of the West Eifel region/Germany and the Grand Duchy of Luxembourg. Ferrantia, 46, 97-115.

Ribbert, K.H., 2007. Lithostratigraphische Einheiten Deutschlands: KlerfFormation. LithoLex, Lithostratigraphisches Lexikon Deutschland, http://litholex.bgr.de/gesamt_ausgabe_neu.php?id=7016035, accessed 01/18/2017.

Ribbert, K.H., 2008. Unterdevon zwischen der Venn-Antiklinale und dem Westrand der Eifeler Kalkmuldenzone. In Deutsche Stratigraphische Kommission (ed.), Stratigraphie von Deutschland VIII: Devon. Schriftenreihe der Deutschen Gesellschaft für Geowissenschaften, 52, 287-296.

Solle, G., 1937. Geologie der mittleren Olkenbacher Mulde. Abhandlungen der Seckenbergischen Naturforschende Gesellschaft, 436, 1-72.

Steemans, P., 1989. Palynostratigraphie de l'Eodévonien dans l'ouest de l'Europe. Mémoires pour servir à l'explication des cartes géologiques et minières de la Belgique, 27, 1-453.

Steemans, P. \& Brasseur, O., 1999. Rapport d'analyse de 60 échantillons de l'Emsien du nord du Grand-Duché de Luxembourg. Inédit, 1-19 ; annexe 1, 1-45 ; annexe 2, 1-74 ; annexe 3, 1-130 ; annexe 4, 1-11.

Steemans, P., Debbaut, V. \& Faber, A., 2000. Preliminary survey of the palynological content of the Lower Devonian of the Oesling, Luxembourg. Bulletin de la Société des naturalistes luxembourgeois, 100, 171-186.

Steininger, J., 1828. Essai d'une description géognostique du GrandDuché de Luxembourg. Académie royale des Sciences et BellesLettres de Bruxelles, Mémoires couronnés, 7, 1-88.

Streel, M., Loboziak, S., Steemans, P. \& Bultynck, P., 2000. Devonian miospore stratigraphy and correlation with the global stratotype sections and points. Courier Forschungsinstitut Senckenberg, 220, 9-23.

Vandenven, G., 1990. Explications de la carte géologique du Synclinorium de l'Eifel (région de Gouvy - Sankt-Vith Elsenborn). Annales de la Société géologique de Belgique, 113/2, 103-113.

Wies, N., 1867. Notice sur les terrains paléozoïques du Grand-Duché de Luxembourg. Bulletin de la Société des sciences naturelles du Grand-Duché de Luxembourg, 9 (1866), 1-20.

Wies, N. \& Siegen, P.M., 1877. Carte géologique du Grand-Duché de Luxembourg à 1/40 000. Section des Sciences naturelles de l'Institut royal Grand-Ducal, Imprimerie Lemercier \& Cie, Paris. 